\title{
Avaliação do desempenho das propriedades mecânicas de concretos self-compacting elaborados com diferentes tipos de cimentos submetidos à cura térmica
}

\section{Avaliação do desempenho das propriedades mecânicas de concretos auto-adensáveis elaborados com diferentes tipos de cimentos submetidos à cura térmica}
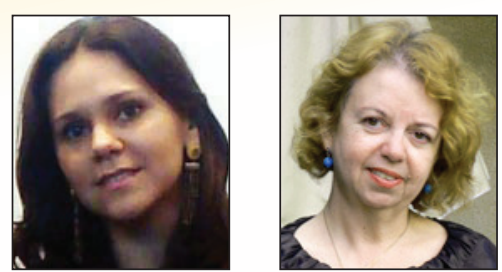

L.F.SANTOS a

liaengenhariacivil@hotmail.com

mbarbosa@dec.feis.unesp.br

\section{Abstract}

Steam curing is one of the mechanisms used in the precast industry to accelerate the strength gain of structural elements. The values of temperature and time of ideal cures for this strength gain vary with the cement and mix design used in concrete. Little is known about the behavior of self-compacting concrete (SCC) when subjected to the steam accelerated curing process, especially with regards to its mechanical properties. This article evaluates the compressive strength of two mixture designs of self-compacting concrete class $40 \mathrm{MPa}$ with two different cements, cement CP III $40-\mathrm{RS}$ and CP II E-32 submitted to normal curing (I accordance with NBR 5738:2003 [2] and to steam curing. Two different steam curing temperatures were used, at $65^{\circ} \mathrm{C}$ and $80^{\circ} \mathrm{C}$ and three curing cycles, $4 \mathrm{~h}, 6 \mathrm{~h}$ and $8 \mathrm{~h}$. The study was done at the Laboratory of Civil Engineering CESP - LCEC - Ilha Solteira/SP, where concretes with specimen cylinders of $10 \mathrm{~cm} \times 20 \mathrm{~cm}$ were tested. The compressive strengths were obtained at the end of the steam curing plateau (called immediate strength to the cycle) and at ages 3, 7, 28, 56 and 91 days (called strength at advanced ages) and for concrete subjected to normal curing, the ages of rupture were performed at 3, 7, 28, 56 and 91 days. An analysis of the correlation was performed between the values of rupture of the concrete subjected to normal cure, with the values of immediate strength to the cycle and also to the strength at advanced ages. The benchmarks were performed according to the type of cement used, curing temperature and time in the steam curing plateau. Overall, the results show that the concrete with cement $\mathrm{CP}$ II E-32 at $65^{\circ} \mathrm{C}$, for the steam curing plateau of 4 hours, was the best compressive strength value when subjected to these curing conditions, while the concrete with cement $\mathrm{CP}$ III $40-\mathrm{RS}$ at $65^{\circ} \mathrm{C}$, for 6 hours of steam curing plateau, was the optimum strength value.

Keywords: self-compacting concrete, compressive strength, steam curing, curing temperature, isothermal plateau.

\section{Resumo}

A cura térmica a vapor é um dos mecanismos utilizados na indústria de pré-moldados para acelerar o ganho da resistência dos elementos estruturais. Os valores de temperatura e tempos de cura ideais para ocorrer esse ganho de resistência variam conforme o cimento e o traço utilizado no concreto. Pouco se conhece sobre o comportamento do concreto auto-adensável (CAA) quando submetido ao processo de cura acelerada a vapor, principalmente em relação as suas propriedades mecânicas. O presente artigo avalia a resistência a compressão de duas composições de concreto auto-adensáveis de classe $40 \mathrm{MPa}$ elaborados com cimentos distintos, cimento CP III 40-RS e cimento CP II E-32 submetidos à cura normal (de acordo com a NBR 5738:2003 [2]) e à cura térmica a vapor. Foram utilizadas duas temperaturas de cura térmica distintas, $65^{\circ} \mathrm{C}$ e $80^{\circ} \mathrm{C}$ e, três patamares isotérmicos, $4 \mathrm{~h}, 6 \mathrm{~h}$ e $8 \mathrm{~h}$. O estudo foi feito no Laboratório CESP de Engenharia Civil - LCEC - Ilha Solteira/SP, onde foram ensaiados corpos-de-prova cilíndricos de $10 \mathrm{~cm} \times 20 \mathrm{~cm}$. As resistências à compressão foram obtidas ao fim do patamar de cura térmica a vapor (denominada resistência imediata ao ciclo) e nas idades de 3, 7, 28, 56 e 91 dias (denominadas resistências nas idades avançadas) e, para os concretos submetidos à cura normal, as idades de ruptura foram realizadas com $3,7,28,56$ e 91 dias. Foram feitas análises de correlação entre os valores de ruptura dos concretos submetidos à cura normal com os valores de resistência imediata ao ciclo e também para as resistências nas idades avançadas. As análises comparativas foram realizadas em função do tipo de cimento empregado, temperatura

de cura e tempo no patamar isotérmico. Os resultados encontrados mostram que em termos globais, o concreto com cimento CP II E-32 apresentou a $65^{\circ} \mathrm{C}$, para o patamar isotérmico de 4 horas o melhor valor de resistência a compressão quando submetido a estas condições de cura, enquanto que o concreto com cimento CP III 40-RS apresentou a $65^{\circ} \mathrm{C}$, para o patamar isotérmico de 6 horas o melhor valor de resistência.

Palavras-chave: concreto auto-adensável, resistência à compressão, cura térmica à vapor, temperatura de cura, patamar isotérmico.

Universidade Estadual Paulista, Departamento de Engenharia Civil, liaengenhariacivil@hotmail.com, Rua 33 n²256, CEP: 15385-000, Ilha Solteira-SP, Brasil.

Universidade Estadual Paulista, Departamento de Engenharia Civil, mbarbosa@dec.feis.unesp.br, Alameda Bahia n550, CEP: 15385-000,

Ilha Solteira-SP, Brasil. 


\section{Introduction}

The self-compacting concrete (SCC) is currently being used in the pre-cast industries in most industrialized countries and is increasingly gaining production ground in the Brazilian industries. Such SCC propagation may be explained by a series of improvements to its application process.

Nunes [1] emphasizes that the self-leveling property of SCC significantly decreases the need to perform horizontal surface elements and finishing on vertical surfaces, which show to be smooth, uniform and free of imperfections. Two factors should be considered in the preparation of precast elements: the large scale production with cyclical elements and the use of techniques that ensure good quality to the final products.

One of the production characteristics of the pre-cast industry is the manufacture of large-scale structural elements, thereby applying methods that will accelerate the compressive strength gain of concrete. One of these methods is the use of steam thermal curing process, which allows accelerating the hydration process of cement, hence resulting in the stiffening of structural elements, facilitating the steps of removing the cast and the handling of the structural elements. Little is known about the behavior of self-compacting concrete when subjected to thermal curing and, moreover, it is known that the pre-cast industries do not often use cement with a high content of mineral admixture, such as the blast furnace Portland cement. Moreover, there is not much research on the production of selfcompacting concrete for pre-cast industries that use steam thermal curing, which use this type of cement.

These concrete industries usually employ purer cements, that is, with a minimum replacement of subproducts (mineral additions), as they are high initial strength cements. Thus, based on this context it was decided to expand the research in this area and to include all these topics, hence the objective of this work was directed to assess the compressive strength of two different SCCs, when subjected to different curing conditions, thermal curing $\left(65^{\circ} \mathrm{C}\right.$ and $80^{\circ} \mathrm{C}$ ) and normal curing (in accordance with NBR 5738:2003 [2]) and using blast furnace Portland cement for these concretes, which use slag as a mineral additive.

\subsection{Justification}

The substitution of high early strength (HES) cement, called by ABNT (Brazilian Technical Standards Association) as CPV- ARI, may be an opportunity to improve the sustainability of the industrial sector, given that in general, Portland is an expensive cement that uses substantial energy to be produced. Considering that a partial replacement of cement by industrial byproducts, which are usually available at a lower cost, could represent savings for the companies and with greater benefits and utilization, which is the case of the cements used in this study, the Portland cement composite (PC II E), in which the addition ranges from $6 \%$ to $34 \%$ in weight, and is specified by the NBR 11.578:1991 [3] and the blast furnace Portland cement (PC III) in which the addition varies from 35\% to $70 \%$ in weight, specified by the NBR 5735:1991 [4].

Furthermore, it is known that to fabricate self-compacting concrete a higher content of paste is reqired, and therefore a greater quantity of cement, when compared to conventional concrete. This larger amount of paste is essential to obtain the required workability this mixture needs, thus, the development of concrete with these little used cement by the companies showed to be a study consistent with the concepts of sustainability that all outstanding enterprises seek to follow.

\section{Self-compacting concrete}

Self-compacting concrete (SCC), according to Okamura [5], is that which is able to keep its passing ability, filling the interior of highly reinforced forms by its own weight only. It is a dense, properly homogeneous material that has no need for compression. It fully resists segregation and maintains its stable composition during transport and concreting, resulting in a more uniform and defect-free product. SCC differs from conventional concrete by presenting three basic properties in its fresh state, namely its passing ability, that is, its ability to fill the empty spaces, ability to pass through restrictions and its ability to resist segregation (WÜSTHOLZ [6])

Therefore, it must meet these requirements, which are reviewed by specific tests that consider its ability to spread and flow. In its fresh state, the self-compacting concrete exhibits from the beginning of its development (phases of the paste, mortar and later the concrete) a rheological behavior of non-Newtonian fluids, Bingham, or even Herschel-Bulkley fluids.

Several studies have been developed to better know and understand the behavior of SCC, either in its fresh or in its hardened state. Some countries, such as the United States, Japan and the European community, have already taken measures to normalize the SCC characterization tests. In Brazil, the first norm for selfcompacting concrete came into force in 2010, NBR 15823:2010 [7].

\subsection{Dosage method of self-compacting concrete}

\section{Testing the paste}

Alencar [8], Tutikian [9] and Melo [10] are some of the Brazilian researchers that propose dosage methods for SCC with proven effectiveness. Among these, the method proposed by Melo [10] addresses the rheological aspects in the concrete dosage, seeking to assess and validate the tests on the paste, mortar and then on the concrete in its fresh state. It was this latter method - called RepeteMelo, illustrated in Figure 1 that was used in this research. Rheological studies on the paste, mortar and concrete in its fresh state were conducted, aiming to use this concrete in a precast industry.

\section{Thermal cure}

The steam thermal curing uses a temperature that is higher than room temperature, this "heating" is the main objective to accelerate the hydration reactions of the cement, resulting in a strength gain, so the concrete can be handled at its early ages.

For Asaga et al. [11], the immediate benefit of thermal curing is to accelerate the initial mechanical strength of concrete. When compared to normal curing, a reduction in the final strength can be observed. This reduction can be attributed to the development of a modified microstructure.

Camarini [12] suggests dividing the thermal curing into four steps:

a) Standby (early period): time elapsed between mixing the binder with water and the start of heating. It must be equal to the cement's setting time. 


\section{Figure 1 - Flowchart of the Repette-Melo determination method (MELO (10))}

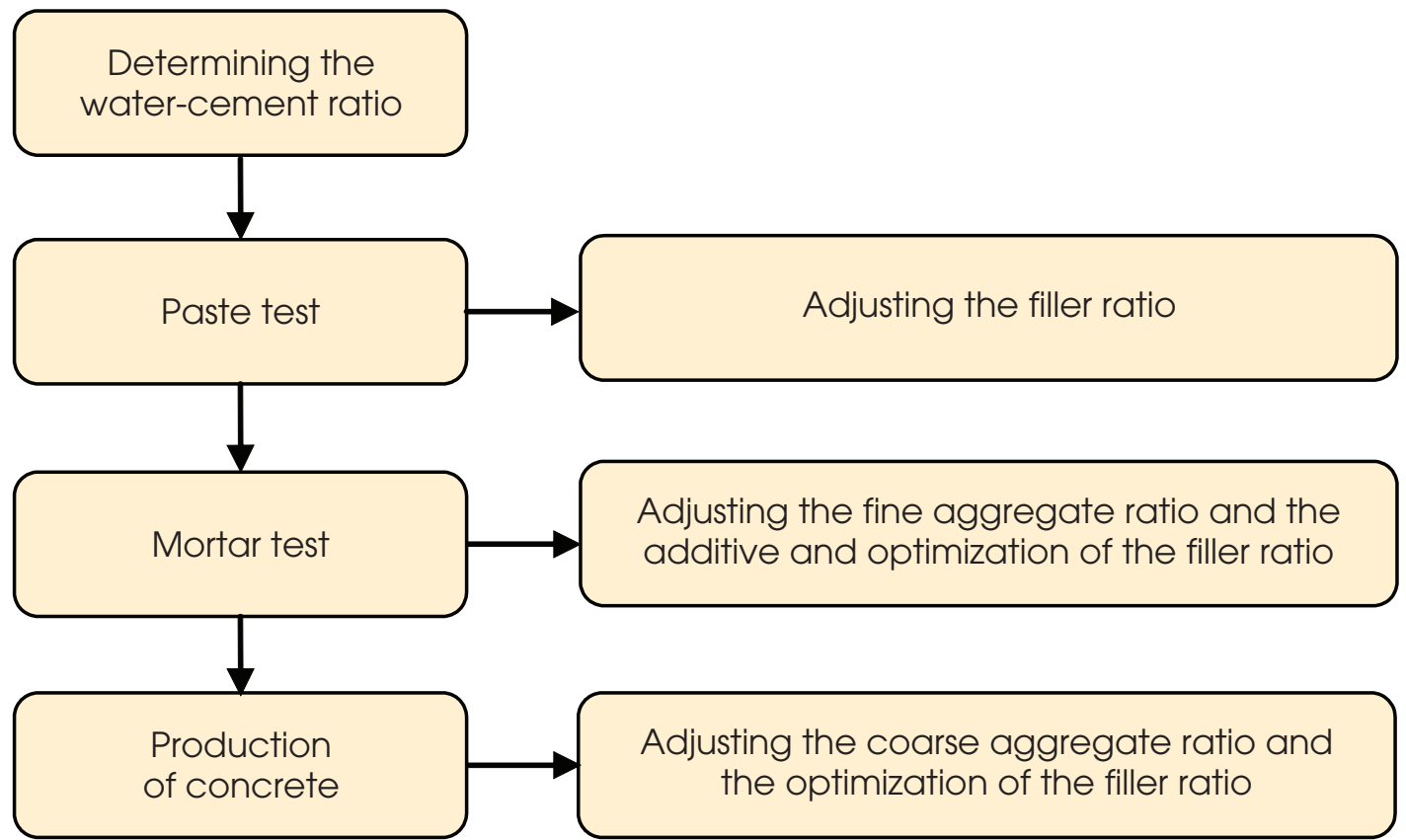

b) Raising the temperature: it must be controlled until the desired value is achieved. The recommended rate is of $20^{\circ} \mathrm{C} / \mathrm{h}$.

c) Isothermal plateau (constant temperature period): a period in which the temperature must be maintained for several hours. This plateau varies depending on the type of binder used. d) Cooling: is the decrease in temperature until room temperature is reached. The recommended rate is of $20^{\circ} \mathrm{C} / \mathrm{h}$.

The same steps of the cycle proposed by Camarini [12] are suggested by El Debs [13], differentiating by about $10^{\circ} \mathrm{C} / \mathrm{h}$ in the thermal cycle, only with respect to the cooling gradient, this thermal cycle is illustrated in Figure 2.

\section{Figure 2 - Typical steam curing cycle (EL DEBS (13))}

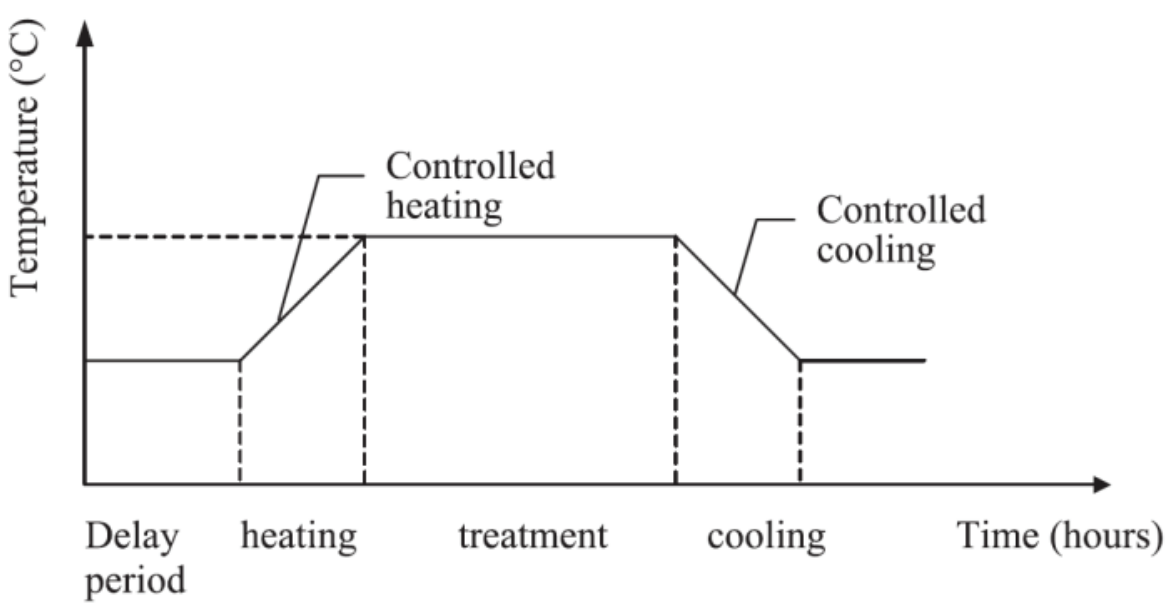


The thermal cycles are used so that the concrete acquires the strength defined in the project, respecting the available time for its completion. The cycle includes the preheating step, at an interval of $2 \mathrm{~h}$ to $5 \mathrm{~h}$, followed by heating, at a rate of $20^{\circ} \mathrm{C} / \mathrm{h}$ to $44^{\circ} \mathrm{C} / \mathrm{h}$ until it reaches the maximum temperature of the cycle, which is between $50^{\circ} \mathrm{C}$ and $82^{\circ} \mathrm{C}$. Next, the cooling of the material is performed, so that the total cycle time does not exceed 18h (ACl [14]). Türkel and Alabas [15] stated that when it is necessary to obtain high levels of initial strength for the deforming criteria, one can apply a maximum curing temperature of $85^{\circ} \mathrm{C}$.

\subsection{Equations of strength at the curing plateau and at advanced ages}

According to Camarini [12], the strength gains at early ages (after the isothermal plateau) or advanced ages (at the required ages) depend on the curing cycle and the maximum temperature adopted. Thus, a comparative analysis was performed on the strengths obtained after the vapor thermal curing and at ages $3,7,28,56$ and 91 days, with the concretes subjected to normal curing, depending on the type of cement used, the temperature and curing time on the isothermal plateau, where the following correlation equations were considered:

To that end, a comparative analysis of the strengths obtained after the steam heating cure cycle, in other words, the strength obtained immediately after the isothermal plateau and before the cooling of the concrete and after the full thermal curing cycle (strength obtained at the end of the isothermal plateau and after the cooling of the concrete), at ages $3,7,28,56$ and 91 with the concretes subjected to normal curing, depending on the type of cement used, the temperature and the curing time on the isothermal plateau, where the following correlation equations were considered:

$$
R(n)=\frac{F_{I C-C T}}{F_{C(i)-C N}}
$$

$$
R(n)=\frac{F_{A C(i)-C T}}{F_{C(i)-C N}}
$$

Where:

$\mathrm{R}(\mathrm{n})$ : Correlation factor, with $\mathrm{n}$ from 1 to 5 for equation 1 and from 6 to 10 for equation 2 ;
$\mathrm{F}_{\mathrm{IC}-\mathrm{CT}}$ : Immediate strength to cycle (thermal curing); (as shown in figure 2);

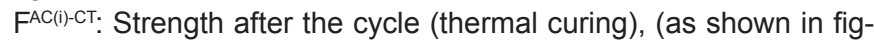
ure 2);

with $i$ the rupture ages: $3,7,28,56$ and 91 ;

$\mathrm{F}_{\mathrm{C}(\mathrm{i})-\mathrm{CN}}$ : Concrete strength (wet cure), with $\mathrm{i}$ the rupture ages: 3,7 , 28,56 and 91.

\section{Effects of curing temperature on concrete with blast furnace Portland cement}

The Brazilian Association of Technical Standards (ABNT) determines the use of slag as mineral admixture in two types of cement and the percentage to be added to its production can vary and is related to the type of cement produced.

For Portland cement composite (CP II E) the addition varies from $6 \%$ to $34 \%$ by weight, and is specified by the NBR $11.578: 1991$ [3]. However for blast furnace Portland cement, (PC III), the addition varies from $35 \%$ to $70 \%$ by weight, which is specified by the NBR 5735:1991 [4].

According to Camarini [12], the degree of cement hydration with slag is initially slower, from $6 \%$ to $8.5 \%$ at 28 days, when compared to the hydration of ordinary Portland cement, and this activity can be accelerated by using some procedures, such as raising the curing temperature.

Overall, Portland cement is expensive and requires a substantial amount of energy to be produced, and a partial replacement of the cement with industrial by-products, which are usually available at a lower cost, could represent savings for companies as well as a better use (CAMARINI [12]).

The industry of pre-cast concrete cement usually uses a purer cement, that is, with a minimum of subproduct replacements, specified as high initial strength Portland cement (CPV-ARI). With the use of blast furnace Portland cement, (CP II E-32 and CP III 40$\mathrm{RS}$ ) the pre-cast industry would benefit by using cements with clinker rates, which justifies expanding the research in this area.

\section{Materials and experimental program}

\subsection{Fine aggregate}

Average sand from the northwest region of São Paulo was used as fine aggregate, with a specific weight of $2.61 \mathrm{~g} / \mathrm{cm}^{3}$, determined according to NBR NM 53:2003 [16], characteristic maximum dimension equal to $2.36 \mathrm{~mm}$ and fineness modulus of $2.01 \mathrm{~mm}$, in accordance with NBR NM 248 [17].

\begin{tabular}{|c|c|c|c|c|}
\hline $\begin{array}{l}\text { Average } \\
\text { size }(\mu \mathrm{m})\end{array}$ & $\begin{array}{l}\text { Size below, where } \\
10 \% \text { of the particles } \\
\text { are found }(\mu \mathrm{m})\end{array}$ & $\begin{array}{l}\text { Size below, where } \\
90 \% \text { of the particles } \\
\text { are found }(\mu \mathrm{m})\end{array}$ & $\begin{array}{l}\text { Material passing } \\
\text { the sieve } n^{\circ} 200 \\
(\%)\end{array}$ & $\begin{array}{l}\text { Specific } \\
\text { weight } \\
\left(\mathrm{g} / \mathrm{cm}^{3}\right)\end{array}$ \\
\hline 45 & 14.4 & 82 & 61.03 & 2.86 \\
\hline
\end{tabular}

\section{Table 1 - Characterization values of the filler}




\subsection{Coarse aggregate}

The coarse aggregate used was crushed basalt, with specific weight of $2.76 \mathrm{~g} / \mathrm{cm}^{3}$, determined in accordance with NBR NM $53: 2003$ [16], characteristic maximum dimension equal to $19 \mathrm{~mm}$ and fineness modulus of $6.31 \mathrm{~mm}$, in accordance with NBR NM 248 [17].

\subsection{Basaltic fillers}

The filler used was a basaltic material and its physical effect is related to its fineness, which helps to fill the voids between the coarse and fine aggregates (TAYLOR [18]). Regarding the chemical effect, in this work the filler was used as an inert material.

A laser granulometry analysis was performed by ABCP - Brazilian Association of Portland Cement, on the basaltic filler used in this research, which showed $60.1 \%$ of particles with diameter less than $75 \mu \mathrm{m}$ and a mean diameter of $45 \mu \mathrm{m}$.

The fraction of the material retained on the $75 \mu \mathrm{m}$ sieve was considered as an integral part of the fine aggregate, which was corrected due to this incorporation. Table 1 shows the main results of the characteristics of the filler.

Table 2 - Physicochemical characterization of cements CP II E-32 and CP III 40-RS

\begin{tabular}{|c|c|c|c|c|c|}
\hline Chemical Analysis (\%) & CP II E-32 & CP III 40-RS & Physical Properties & CP II E-32 & CP III 40-RS \\
\hline Loss on ignition & 4,33 & 3,47 & $\begin{array}{l}\text { Sieve Fineness } \\
200 \text { (\% retained) }\end{array}$ & 4,93 & 0,28 \\
\hline Insoluble & 1,63 & 0,7 & $\begin{array}{c}\text { Sieve Fineness } \\
325 \text { (\% retained) }\end{array}$ & 16,8 & 1,02 \\
\hline $\mathrm{SiO}_{2}$ & 20,75 & 24,52 & $\begin{array}{c}\text { Surface Specific } \\
\text { Blaine }\left(\mathrm{cm}^{2} / \mathrm{g}\right)\end{array}$ & 4031 & 4180 \\
\hline $\mathrm{Fe}_{2} \mathrm{O}_{3}$ & 2,29 & 2,29 & $\begin{array}{c}\text { Apparent Density } \\
\left(\mathrm{g} / \mathrm{cm}^{3}\right)\end{array}$ & 1,09 & 1,01 \\
\hline $\mathrm{Al}_{2} \mathrm{O}_{3}$ & 8,05 & 9,49 & $\begin{array}{l}\text { Absolute density } \\
\qquad\left(\mathrm{g} / \mathrm{cm}^{3}\right)\end{array}$ & 3,05 & 2,99 \\
\hline $\mathrm{CaO}$ & 57,45 & 53,12 & $\begin{array}{l}\text { Initial adherence } \\
\text { (h:min) }\end{array}$ & $02: 43$ & $02: 51$ \\
\hline $\mathrm{MgO}$ & 1,89 & 3,12 & $\begin{array}{c}\text { Concluding } \\
\text { adherence (h:min) }\end{array}$ & $04: 06$ & $04: 52$ \\
\hline $\mathrm{SO}_{3}$ & 2,44 & 1,98 & $\begin{array}{c}\text { Autoclave } \\
\text { Expansion (\%) }\end{array}$ & 0,032 & 0,003 \\
\hline $\mathrm{Na}_{2} \mathrm{O}$ & 0,26 & 0,26 & Stress (MPa) 03 days & 19,4 & 23,8 \\
\hline $\mathrm{K}_{2} \mathrm{O}$ & 0,58 & 0,58 & Stress (MPa) 07 days & 24,4 & 30,7 \\
\hline Equiv. alkaline $\mathrm{Na}_{2} \mathrm{O}$ & 0,64 & 0,64 & Stress (MPa) 28 days & 32,1 & 37,9 \\
\hline Free lime in $\mathrm{CaO}$ & 1,69 & 1,06 & $a / c$ & 0,48 & 0,48 \\
\hline
\end{tabular}




\section{Table 3 - Composition of SCC}

\begin{tabular}{cccccccc}
$\begin{array}{c}\text { Description of } \\
\text { Concrete }\end{array}$ & Ratio a/c & $\begin{array}{c}\text { Cement } \\
\text { mass } \\
\left(\mathrm{Kg} / \mathrm{m}^{3}\right)\end{array}$ & $\begin{array}{c}\text { Filler } \\
\text { mass } \\
\left(\mathrm{Kg} / \mathrm{m}^{3}\right)\end{array}$ & $\begin{array}{c}\text { Sand } \\
\text { mass } \\
\left(\mathrm{Kg} / \mathrm{m}^{3}\right)\end{array}$ & $\begin{array}{c}\text { Gravel } \\
\text { mass } \\
\left(\mathrm{Kg} / \mathrm{m}^{3}\right)\end{array}$ & $\begin{array}{c}\text { Cement } \\
\text { content } \\
(\mathrm{l})\end{array}$ & $\mathrm{f}_{28}(\mathrm{MPa})$ \\
$\begin{array}{c}\text { Concrete A } \\
\text { CPII E-32 }\end{array}$ & 0,40 & 478,90 & 202,07 & 704,61 & 816,76 & 2,07 & 50,30 \\
$\begin{array}{c}\text { Concrete B } \\
\text { CPIII 40 RS }\end{array}$ & 0,48 & 450,86 & 205,94 & 678,11 & 875,10 & 2,10 & 44,00 \\
\hline
\end{tabular}

\subsection{Portland cement}

The Blast Furnace Portland cements were used as hydraulic binder, designated and classified by the Brazilian standards as cement CP II E-32 and CP III 40-RS. The potential compositions of the cements and the physical characteristics of the paste are detailed in Table 2.

\subsection{Composition of self-compacting concrete}

The composition of self-compacting concrete was divided into five phases and its experimental procedure was based on the methodology by Repete-Melo - Melo [10]. However, adjustments in some stages of the procedure were required, according to the variation of the materials used in the manufacture of this concrete. These steps are described and chronologically numbered below.

1. The selection and characterization of the materials chosen were carried out to prepare the SCC;

2. The second step was to manufacture a conventional concrete using the IPT/EPUSP method to find an a/c ratio that meets the required compressive strength of $40 \mathrm{MPa}$ at 28 days. In this test an a/c ratio was determined for each type of cement used in the research;

3. With the value of the a/c ratio for each type of cement, the paste phase began, when an adjustment of the filler and adjustment of the additive were performed, with these adjustments found by the Marsh cone test and with the Rheometer test;

4. The mortar stage was next, when the fine aggregate was adjusted, a better adjustment of the filler and of the additive. The procedure used was the spreading test, funnel- $V$, the test with the Rheometer and the monitoring of the compressive strength values of these mixtures;

5. Finally, the concrete test, when only the adjustment of the coarse aggregate and of the additive was performed.

6. The procedure adopted for the slump-flow test, funnel-V, box-L, segregation (Column technique) and evaluation of the mechanical properties of the concrete by checking that the required values were met.

Table 3 describes the composition of SCC.

\subsection{Steam thermal curing test}

The thermal curing was carried out in steam heat chamber at atmospheric pressure, in accordance with the thermal gradient described below.
- Waiting time $\left(\mathrm{t}_{0}\right)$ : coincides with the setting time of the cement. The determined setting time of concrete was of $3 \mathrm{~h}$ and of $30 \mathrm{~min}$ for both types of cements used.

- Gradient of raising temperature $\left(\mathrm{t}_{1}\right)$ : Test specimens placed in the steam heat chamber equipment (Figure 3 ), and subjected to a controlled maximum temperature of $25^{\circ} \mathrm{C} / \mathrm{h}$.

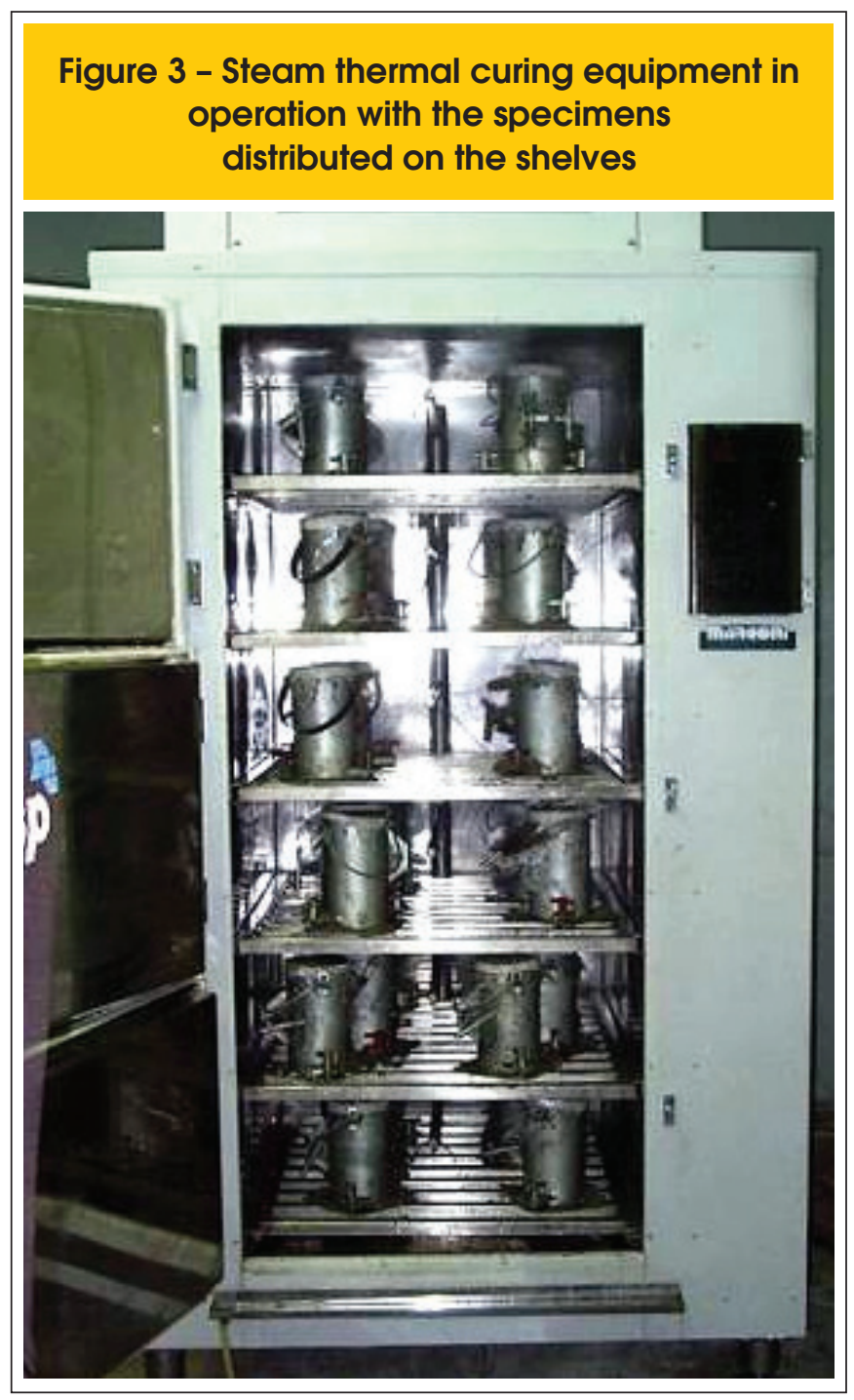


Table 4 - Details of the isothermal plateaus on the concretes tested

\begin{tabular}{|c|c|c|c|c|c|c|c|c|}
\hline \multicolumn{2}{|c|}{ Waiting Period } & \multicolumn{2}{|c|}{ Heating $\left(25^{\circ} \mathrm{C} / \mathrm{h}\right)$} & \multicolumn{2}{|c|}{ Curing Time } & \multicolumn{2}{|c|}{ Cooling $\left(18^{\circ} \mathrm{C} / \mathrm{h}\right)$} & \multirow{2}{*}{$\begin{array}{c}\text { Total Cycle } \\
\text { Time } \\
\text { (h:min) }\end{array}$} \\
\hline $\begin{array}{l}\text { Temp. } \\
\left({ }^{\circ} \mathrm{C}\right)\end{array}$ & $\begin{array}{l}\text { Time } \\
\text { (h:min) }\end{array}$ & $\begin{array}{l}\text { Temp. } \\
\left({ }^{\circ} \mathrm{C}\right)\end{array}$ & $\begin{array}{l}\text { Time } \\
\text { (h:min) }\end{array}$ & $\begin{array}{c}\text { Temp. } \\
\left({ }^{\circ} \mathrm{C}\right)\end{array}$ & $\begin{array}{l}\text { Time } \\
\text { (h:min) }\end{array}$ & $\begin{array}{c}\text { Temp. } \\
\left({ }^{\circ} \mathrm{C}\right)\end{array}$ & $\begin{array}{c}\text { Time } \\
(\mathrm{h}: \mathrm{min})\end{array}$ & \\
\hline 27 & $03: 30$ & $27-65$ & $01: 30$ & 65 & 4 & $65-30$ & $02: 00$ & $11: 00$ \\
\hline 27 & $03: 30$ & $27-65$ & $01: 30$ & 65 & 6 & $65-30$ & $02: 00$ & $13: 00$ \\
\hline 27 & 03:30 & $27-65$ & $01: 30$ & 65 & 8 & $65-30$ & $02: 00$ & $15: 00$ \\
\hline 27 & $03: 30$ & $27-80$ & $02: 10$ & 80 & 4 & $80-30$ & $02: 50$ & $12: 30$ \\
\hline 27 & $03: 30$ & $27-80$ & $02: 10$ & 80 & 6 & $80-30$ & $02: 50$ & $14: 30$ \\
\hline 27 & $03: 30$ & $27-80$ & $02: 10$ & 80 & 8 & $80-30$ & $02: 50$ & $16: 30$ \\
\hline
\end{tabular}

- Isothermal plateau $\left(t_{2}\right)=$ maintenance of maximum curing temperature. Periods of 4,6 and 8 hours and curing temperatures of $65^{\circ} \mathrm{C}$ and $80^{\circ} \mathrm{C}$ were used. After the isothermal plateau period, three test specimens were removed from the thermal curing equipment and broken, which are called FIC-CT (immediate ruptures to the cycle).

- Cooling gradient $\left(\mathrm{t}_{3}\right)$ : decreasing of the temperature controlled at $18{ }^{\circ} \mathrm{C} / \mathrm{h}$. At the end of each cycle, the specimens were demolded and placed in a saturated moist chamber, remaining in this chamber until the stipulated ages for rupture $(3,7,28,56$ and 91 days). These specimens were designated FAC-CT (ruptures after the cycle).
12 (twelve) thermal curing tests were performed, 6 (six) for each type of cement, varying the isothermal plateau temperature: $65^{\circ} \mathrm{C}$ and $80^{\circ} \mathrm{C}$, and the period of this plateau: 4,6 and 8 hours, as demonstrated in Table 4.

For each test, the concretes were subjected to normal curing, when the samples remained in the molds for 24 hours at room temperature and at the end of this period they were demolded, remaining in a saturated moist chamber to be broken.

\section{Results and discussions}

From the proposed test program, the compressive strength of the

Table 5 - Compressive strength analysis of the curing plateau of SCC

\begin{tabular}{|c|c|c|c|c|c|c|c|}
\hline \multirow{2}{*}{\multicolumn{2}{|c|}{ Condition Plateau (h) }} & \multirow{2}{*}{$\begin{array}{l}\text { Immediate } \\
\text { strength to } \\
\text { the cycle } \\
\text { (MPa) }\end{array}$} & \multicolumn{5}{|c|}{$\begin{array}{l}\text { Analysis of immediate strength to the thermal curingcycle - } \\
\text { Cement II and CP-32 }\end{array}$} \\
\hline & & & R1 (\%) & R2 (\%) & R3 (\%) & R4 (\%) & R5 (\%) \\
\hline \multirow{3}{*}{$\begin{array}{l}\text { Cure } \\
65^{\circ} \mathrm{C}\end{array}$} & 4 & 17,4 & 50 & 41 & 34 & 33 & 30 \\
\hline & 6 & 18,8 & 54 & 44 & 37 & 35 & 32 \\
\hline & 8 & 18 & 52 & 42 & 36 & 34 & 31 \\
\hline \multirow{3}{*}{$\begin{array}{l}\text { Cure } \\
80^{\circ} \mathrm{C}\end{array}$} & 4 & 18,2 & 52 & 43 & 36 & 34 & 31 \\
\hline & 6 & 18,4 & 53 & 43 & 36 & 34 & 32 \\
\hline & 8 & 19,6 & 53 & 46 & 39 & 37 & 34 \\
\hline \multicolumn{2}{|c|}{ Ambient curing (MPa) } & - & $f_{c 3}-34,9$ & $f_{c 7}-42,5$ & $f_{c 28}-50,7$ & $f_{c 56}-53,4$ & $f_{c 91}-58,1$ \\
\hline
\end{tabular}


Table 6 - Compressive strength analysis at advanced ages of SCC

\begin{tabular}{|c|c|c|c|c|c|c|c|c|c|c|c|}
\hline \multirow[b]{2}{*}{ Condition } & \multirow{2}{*}{$\begin{array}{c}\text { Plateau } \\
\text { (h) }\end{array}$} & \multicolumn{10}{|c|}{ Analysis of strength after the thermal cure cycle (MPa) - Cement CP II-E } \\
\hline & & $\begin{array}{l}3 \text { days } \\
(72 h)\end{array}$ & $\begin{array}{l}\text { R6 } \\
(\%)\end{array}$ & $\begin{array}{l}7 \text { days } \\
\text { (168h) }\end{array}$ & $\begin{array}{l}\text { R7 } \\
(\%)\end{array}$ & $\begin{array}{c}28 \text { days } \\
(672 h)\end{array}$ & $\begin{array}{l}\text { R8 } \\
(\%)\end{array}$ & $\begin{array}{l}56 \text { days } \\
\text { (1344h) }\end{array}$ & $\begin{array}{l}\text { R9 } \\
(\%)\end{array}$ & $\begin{array}{l}91 \text { days } \\
\text { (2184h) }\end{array}$ & $\begin{array}{l}\text { R10 } \\
(\%)\end{array}$ \\
\hline \multirow{3}{*}{$\begin{array}{l}\text { Cure } \\
65^{\circ} \mathrm{C}\end{array}$} & 4 & 33,9 & 97 & 40,4 & 95 & 48,5 & 95 & 54,2 & 101 & 54,7 & 94 \\
\hline & 6 & 28,2 & 81 & 36,3 & 85 & 44,7 & 88 & 45,5 & 85 & 49,5 & 85 \\
\hline & 8 & 29,5 & 85 & 34,5 & 81 & 40,5 & 80 & 40,6 & 76 & 43,6 & 75 \\
\hline \multirow{3}{*}{$\begin{array}{l}\text { Cure } \\
80^{\circ} \mathrm{C}\end{array}$} & 4 & 22,4 & 64 & 26,4 & 62 & 37,2 & 73 & 41,6 & 8 & 42,5 & 73 \\
\hline & 6 & 22,3 & 64 & 26,3 & 62 & 36,4 & 72 & 40,4 & 76 & 45,6 & 78 \\
\hline & 8 & 21,7 & 62 & 27,8 & 65 & 32,5 & 64 & 32,6 & 61 & 33,1 & 57 \\
\hline $\begin{array}{l}\text { Ambient cure } \\
(\mathrm{MPa})\end{array}$ & & $f_{c 3}-34,9$ & - & $f_{c 7}-42,5$ & - & $f_{c 2} 8-50,7$ & - & $f_{c 56}-53,4$ & - & $f_{c 91}-58,1$ & - \\
\hline
\end{tabular}

specimens was obtained and the correlations between the immediate strengths to the cycle and at advanced ages were established for the SCC prepared with different types of cement.

\subsection{Self-compacting concrete prepared with CP II E-32 cement}

Table 5 refers to the immediate strength analysis to the cycle, and outlines the analysis of the relative variations of the results regarding the SCC strength subjected to normal curing.

The values of variance analysis in Table 5 , which correlated the results of resistance to cycle through immediate resistance from the CAA in healing environment, proved to be consistent because, as expected, it was possible to note an increase in the value of resistance of concrete with increasing temperature and time of isothermal plateau.

The analysis values of the relative variations of the results in Table 5, where the immediate results of strength to the cycle (at the end of the steam heating cure cycle and before cooling) were correlated by the SCC strength in a curing environment, proved to be consistent because, as expected, an increase was noted in the strength value of the concretes, with increasing temperature

\begin{tabular}{|c|c|c|c|c|c|c|c|}
\hline \multicolumn{8}{|c|}{ Table 7 - Analysis of the strength in the curing plateau of SCC } \\
\hline \multirow[t]{2}{*}{ Condition } & \multirow{2}{*}{$\begin{array}{l}\text { Plateau } \\
\text { (h) }\end{array}$} & \multirow{2}{*}{$\begin{array}{l}\text { Immediate } \\
\text { strength to } \\
\text { the cycle } \\
\text { (MPa) }\end{array}$} & \multicolumn{5}{|c|}{$\begin{array}{l}\text { Analysis of immediate strength to thermal cycling - } \\
\text { Cement CP III 40-RS }\end{array}$} \\
\hline & & & R1 (\%) & R2 (\%) & R3 (\%) & R4 (\%) & R5 (\%) \\
\hline \multirow{3}{*}{ Cure $65^{\circ} \mathrm{C}$} & 4 & 10,1 & 45 & 30 & 23 & 22 & 21 \\
\hline & 6 & 10,2 & 45 & 30 & 23 & 22 & 21 \\
\hline & 8 & 12,8 & 56 & 38 & 29 & 28 & 26 \\
\hline \multirow{3}{*}{ Cure $80^{\circ} \mathrm{C}$} & 4 & 10,9 & 48 & 32 & 25 & 24 & 23 \\
\hline & 6 & 11,3 & 50 & 33 & 26 & 25 & 23 \\
\hline & 8 & 14,1 & 62 & 42 & 32 & 31 & 29 \\
\hline \multicolumn{2}{|c|}{ Ambient cure (MPa) } & - & $f_{c 3}-22,7$ & $f_{c 7}-33,8$ & $f_{c 28}-44$ & $f_{c 50}-45,7$ & $f_{c 91}-48,4$ \\
\hline
\end{tabular}


Table 8 - Analysis of strength in the advanced ages of the SCC

\begin{tabular}{|c|c|c|c|c|c|c|c|c|c|c|c|}
\hline \multirow[b]{2}{*}{ Condition } & \multirow{2}{*}{$\begin{array}{l}\text { Plateau } \\
\text { (h) }\end{array}$} & \multicolumn{10}{|c|}{ Analysis of the strength after the heat cycle (MPa) - Cement CP III 40-RS } \\
\hline & & $\begin{array}{c}3 \text { days } \\
\text { (72h) }\end{array}$ & $\begin{array}{l}\text { R6 } \\
(\%)\end{array}$ & $\begin{array}{l}7 \text { days } \\
\text { (168h) }\end{array}$ & $\begin{array}{l}\text { R7 } \\
(\%)\end{array}$ & $\begin{array}{c}28 \text { days } \\
(672 h)\end{array}$ & $\begin{array}{l}\text { R8 } \\
(\%)\end{array}$ & $\begin{array}{l}56 \text { days } \\
\text { (1344h) }\end{array}$ & $\begin{array}{l}\text { R9 } \\
(\%)\end{array}$ & $\begin{array}{l}91 \text { days } \\
\text { (2184h) }\end{array}$ & $\begin{array}{l}\text { R10 } \\
(\%)\end{array}$ \\
\hline \multirow{3}{*}{$\begin{array}{l}\text { Cure } \\
65^{\circ} \mathrm{C}\end{array}$} & 4 & 22,9 & 101 & 33,2 & 98 & 41,2 & 94 & 37,3 & 82 & 43,5 & 90 \\
\hline & 6 & 23,9 & 105 & 30,7 & 91 & 43 & 98 & 43,6 & 95 & 44,8 & 93 \\
\hline & 8 & 23,9 & 105 & 29,7 & 88 & 40 & 91 & 42,9 & 94 & 46,9 & 97 \\
\hline \multirow{3}{*}{$\begin{array}{l}\text { Cure } \\
80^{\circ} \mathrm{C}\end{array}$} & 4 & 26,2 & 115 & 29,6 & 88 & 36 & 82 & 37,5 & 82 & 39,9 & 82 \\
\hline & 6 & 24,1 & 106 & 26,1 & 77 & 39 & 71 & 32,6 & 71 & 35,8 & 74 \\
\hline & 8 & 18,8 & 83 & 20,2 & 60 & 23,2 & 53 & 29,9 & 65 & 30 & 62 \\
\hline \multicolumn{2}{|c|}{ Ambient cure (MPa) } & $f_{c 3}-22,7$ & - & $f_{c 7}-33,8$ & - & $f_{c 28}-44$ & - & $f_{c 56}-45,7$ & - & $f_{c 91}-48,4$ & - \\
\hline
\end{tabular}

and time of the isothermal plateau. Under these conditions, the cure cycle with higher initial strength at a temperature of $65^{\circ} \mathrm{C}$ was the isotherm plateau of 6 hours, in other words, in this short span of time it was possible to obtain, with regards to the normal curing values, $54 \%$ of the strength obtained at 3 days (R1 $=54 \%)$ and $37 \%$ of the strength reached at 28 days $(R 3=37 \%)$. For the temperature of $80^{\circ} \mathrm{C}$, it was the isotherm plateau of 8 hours, that is, in this short span of time it was possible to obtain, with regards to the normal curing values, $53 \%$ of the strength obtained at 3 days $(\mathrm{R} 1=53 \%)$, and $39 \%$ of the strength reached at 28 days (R3 $=39 \%)$.

Table 6 refers to the analysis of strength after the full cycle and outlines the analysis of the variations relative to the results regarding the SCC strength subjected to normal curing.

By observing the values of the analysis on the relative variations of the results at advanced ages, indicated in Table 6 , the best concrete performance results were for the temperature of $65^{\circ} \mathrm{C}$ with the isotherm plateau of 4 hours, in other words, with losses below $6 \%$ at all ages $(\mathrm{R} 6=97 \% ; \mathrm{R} 7=97 \% ; \mathrm{R} 8=95 \% ; \mathrm{R} 9=101 \%$; $\mathrm{R} 10=94 \%$ ). The temperature of $80{ }^{\circ} \mathrm{C}$ showed large losses in strength, when compared to the values obtained at a temperature of $65^{\circ} \mathrm{C}$, with the results of the analysis on the relative variations for all isothermal plateaus lower than $80 \%$, that is, losses above $20 \%$ for strength values.

\subsection{Self-compacting concrete prepared with cement CP III 40-RS}

The compression strength of the samples was also obtained and the correlation between the cycle and immediate strength at advanced ages was established for the SCC, with cement CP III 40RS, shown in Table 7 and Table 8.

Table 7 refers to the immediate strength analysis to the cycle, and outlines the analysis of the relative variations in the results regarding the strength of SCC subjected to normal curing.

The analysis of the variations in the results of immediate strength to the cycle for this SCC showed to be consistent, because, as expected, it noted an increase in the strength value of the concretes with increasing temperature and time of the isothermal plateau. Under these conditions, the cure cycle with the highest initial strength, for a temperature of $65^{\circ} \mathrm{C}$, was the isotherm plateau of 8 hours, that is, in this short span of time it was possible to obtain, with regards to the normal curing values, $56 \%$ of the strength obtained at 3 days and $29 \%$ of the strength reached at 28 days (R3 $=29 \%$ ). For the temperature of $80{ }^{\circ} \mathrm{C}$, it was also the isothermal plateau of 8 hours, that is, in this short span of time it was possible to obtain, with regards to the normal curing values, $62 \%$ of the strength obtained at 3 days $(\mathrm{R} 1=62 \%)$ and $32 \%$ of the resistance reached at 28 days $(\mathrm{R} 3=32 \%)$.

Table 8 refers to the analysis of strength after the cycle, and outlines the analysis of the variations of the results regarding the strength of SCC subjected to normal curing.

By observing the values in the analysis of the relative variations of the results at advanced ages, indicated in Table 8, the best performance result of the concrete was for the temperature at $65^{\circ} \mathrm{C}$, with the isotherm plateau of 6 hours, that is, a $5 \%$ strength gain at day $3(R 6=105 \%)$ and a loss of only $2 \%$ at 28 days $(R 8=98 \%)$. Although the concrete performance of the temperature at $80^{\circ} \mathrm{C}$ for the isotherm plateau of 4 hours showed a $15 \%$ strength increase at day $3(R 6=115 \%)$, considering the strength at ages 28,56 and 91 days, the strength loss was of $18 \%$ for these ages (R8 $=82 \%$; $\mathrm{R} 9=82 \% ; \mathrm{R} 10=82 \%)$.

\subsection{Comparative analysis of SCC with cement CP II E-32 and cement CP III 40-RS for a $65^{\circ} \mathrm{C}$ temperature}

After the individual analysis of the concretes, a comparative analysis between both SCCs was carried out, assessing their efficiency when compared to the compressive strength values for the concretes subjected to normal curing, by means of the analysis of the relative variations of the results. 


\section{Figure 4 - Comparative analysis between the concretes studied (CAA1: concrete prepared with cement CP II E-32 and CAA2: concrete prepared with cement CP III 40-RS)}

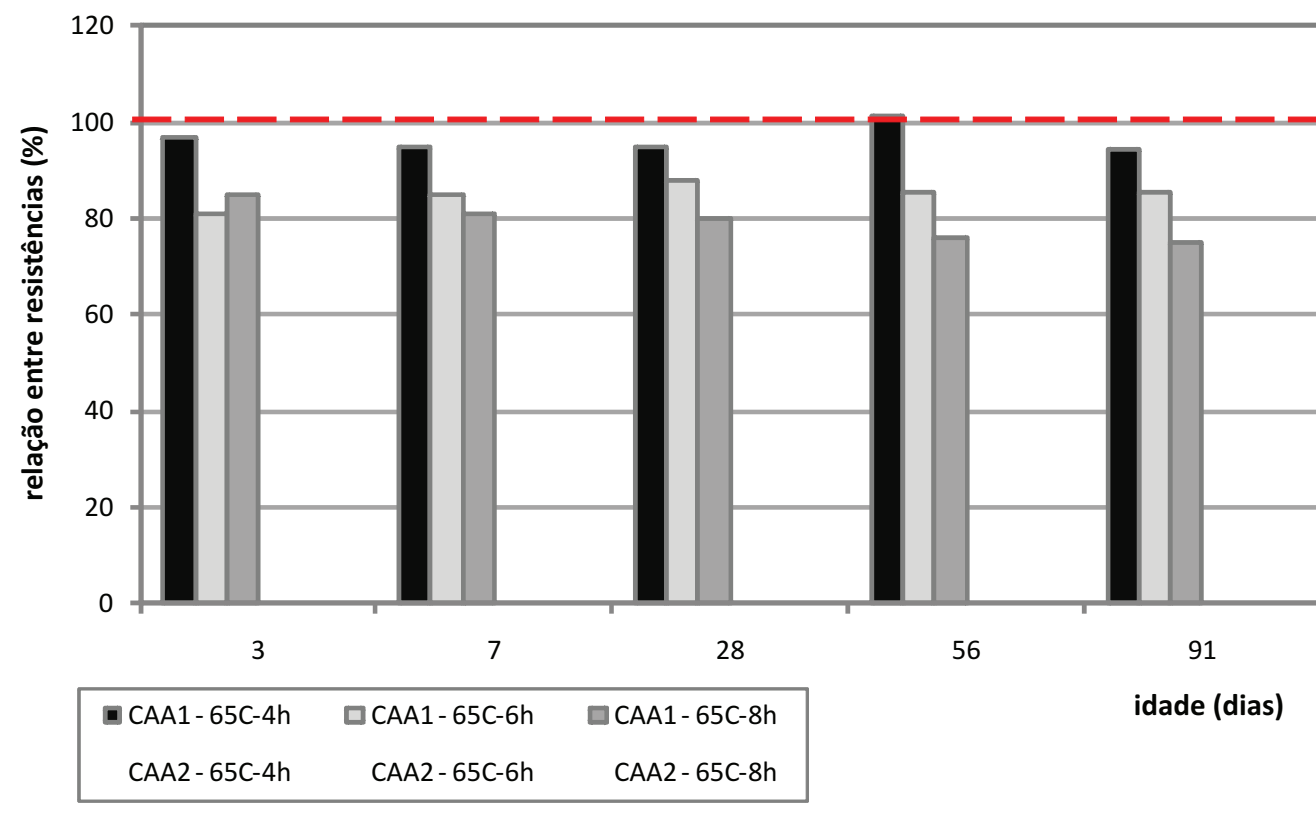

Figure 4 shows the bar graph with a comparative analysis of both concretes regarding their strength after the cycle, set at temperature of $65^{\circ} \mathrm{C}$ for the three curing times studied $(4 \mathrm{~h}, 6 \mathrm{~h}$ and $8 \mathrm{~h}$ ).

The percentage of $100 \%$ is the actual value of the compressive strength of the concretes subjected to normal curing, which is indicated when the concrete subjected to thermal curing gives the same compressive strength value of the concrete subjected to normal curing and if the percentage is greater than $100 \%$, it means that the concrete subjected to thermal curing showed a higher strength value than the value found for the same concrete subjected to normal curing, and vice versa.

Thus, despite SCC2 indicating lower values of compressive strength in our results, when compared to SCC1, when analyzing the performance of SCC2 for its strength to normal curing, one can see that for the $65^{\circ} \mathrm{C}$ temperature, its efficiency showed significant gains, higher than the gains in strength for SCC1.

\subsection{Comparative analysis of SCC with cement CP II E-32 and SCC with cement CP III 40-RS for the temperature of $80^{\circ} \mathrm{C}$}

Using the same data analysis procedure described in Section 6.3 , Figure 5 shows the bar graph with a comparative analysis on strength for both concretes after the cycle, set at a temperature of $80^{\circ} \mathrm{C}$ for the three curing times studied ( $4 \mathrm{~h}, 6 \mathrm{~h}$ and $8 \mathrm{~h}$ ).

Given that the percentage of $100 \%$ is the actual value of the compressive strength of the concretes subjected to normal curing, it is noted that the SCC2, for higher temperatures, showed an efficiency yield well above the efficiency yield of SCC1. This demonstrates that the SCC2 shows better performance with longer isothermal regimes.

\section{Conclusions}

This paper presents the performance assessment of self-compacting concretes using Portland cement with blast-furnace granulated slag, when subjected to steam thermal curing.

The final results for the self-compacting concrete showed to be similar to that of conventional concretes when the steam heating cure is used, that is, there were no changes in the results that justify the influence of SCC on the final results, when compared to the conventional concrete.

The results of the compressive strength of concrete indicated that, as expected, with increasing temperature there was an acceleration of the kinetics of hydration reactions, favoring the concrete's gain in strength at early ages. The stage of the isothermal regime is directly related to the maximum curing temperature and type of cement used.

The two types of concretes studied, (whose compositions differ in the type of cement used), showed better performance with longer isothermal regimes and, when subjected to lower temperatures, the shorter regimes provide better final strengths.

By increasing the temperature and prolonging the curing period, the early strength improved, but there was no increase in strength with age. Each concrete assessed demonstrated its own steam curing thermal performance and a single cure cycle cannot be established for both types of CAA studied.

It was concluded that, overall, the concrete with cement CP II E-32 at $65^{\circ} \mathrm{C}$ demonstrated the best compressive strength value for the isothermal plateau of 4 hours, when subjected to these curing conditions. The concrete with cement CP III 40-RS at $65^{\circ} \mathrm{C}$, demonstrated the best compressive strength value for the isothermal plateau of 6 hours, when subjected to these curing conditions. 
Significant concrete strength yields over time after the use of high curing temperatures should not be expected, as such curing temperatures affect the agglomerant's performance.

When comparing the compressive strength results of both types of concrete prepared after the cure cycle, at a temperature of 65 ${ }^{\circ} \mathrm{C}$, it was possible to obtain, regarding the normal curing values, most of the values above $80 \%$. As for the $80{ }^{\circ} \mathrm{C}$ temperature, most values fell below $80 \%$.

With the comparative analysis of both concretes, it was concluded that the cement CP III 40-RS performed better with longer isothermal regimes.

It was further concluded that, upon analyzing the physical and chemical properties of each cement, the cement with the greatest amount of slag (CP III 40-RS) may have had the best performance in longer regimes precisely because there is a larger amount slag in its composition (from $35 \%$ to $70 \%$ of slag in its composition), since the hydration reactions of slag cements have their speed controlled mainly by the quantity and reactivity of slag, type and concentration of the activator and temperature.

By observing the physical analysis of the cements, the cement CP III 40-RS has a larger amount of fines (passing through sieve \# 325), and also a higher initial strength of the paste when compared with the cement CP II E-32. These factors may be related to the better performance of this cement, both at early ages as well as at the final ages (using the curing process).

Some more detailed studies on cement and concrete, such as Xray diffraction and scanning electron microscopy, could more precisely clarify the influence of the properties of each cement in the final results of concrete curing.

\section{Acknowledgements}

The authors thank the Energy Company of São Paulo - CESP - for the availability of test results performed at the CESP Laboratory of Civil Engineering at Ilha Solteira-SP.

We also thank the UNESP Laboratory of Civil Engineering at Ilha Solteira for their availability and assistance.

To FAPESP for the financial assistance to the research project To HOLCIM for supplying the cement and SIKA for the donation of the superplasticizer additive.

\section{Bibliographic references}

[01] NUNES, S. C. B. Betão auto-compactável: Tecnologia e propriedades. Pós-graduação em Estruturas de Engenharia Civil - Faculdade de Engenharia, Universidade do Porto, 198p, 2001.

[02] ASSOCIAÇÃO BRASILEIRA DE NORMAS TÉCNICAS - ABNT. Concreto - Moldagem e cura de corpos-de-prova cilíndricos ou prismáticos de concreto. NBR 5738. Rio de Janeiro, 2003.6p

[03] ABNT. Cimento Portland Composto. - NBR 11578, Rio de Janeiro, 1991.

[04] ABNT. Cimento Potland de alto-forno. NBR 5735. Rio de Janeiro, 1991.

[05] OKAMURA, H. Self-Compacting High-Performance Concrete. Concrete International, Vol. 19, No. 7, pp. 50-54, 1997.

\section{Figure 5 - Comparative analysis between the concretes studied (CAA1: concrete prepared with cement CP II E-32 and CAA2: concrete prepared with cement CP III 40-RS)}

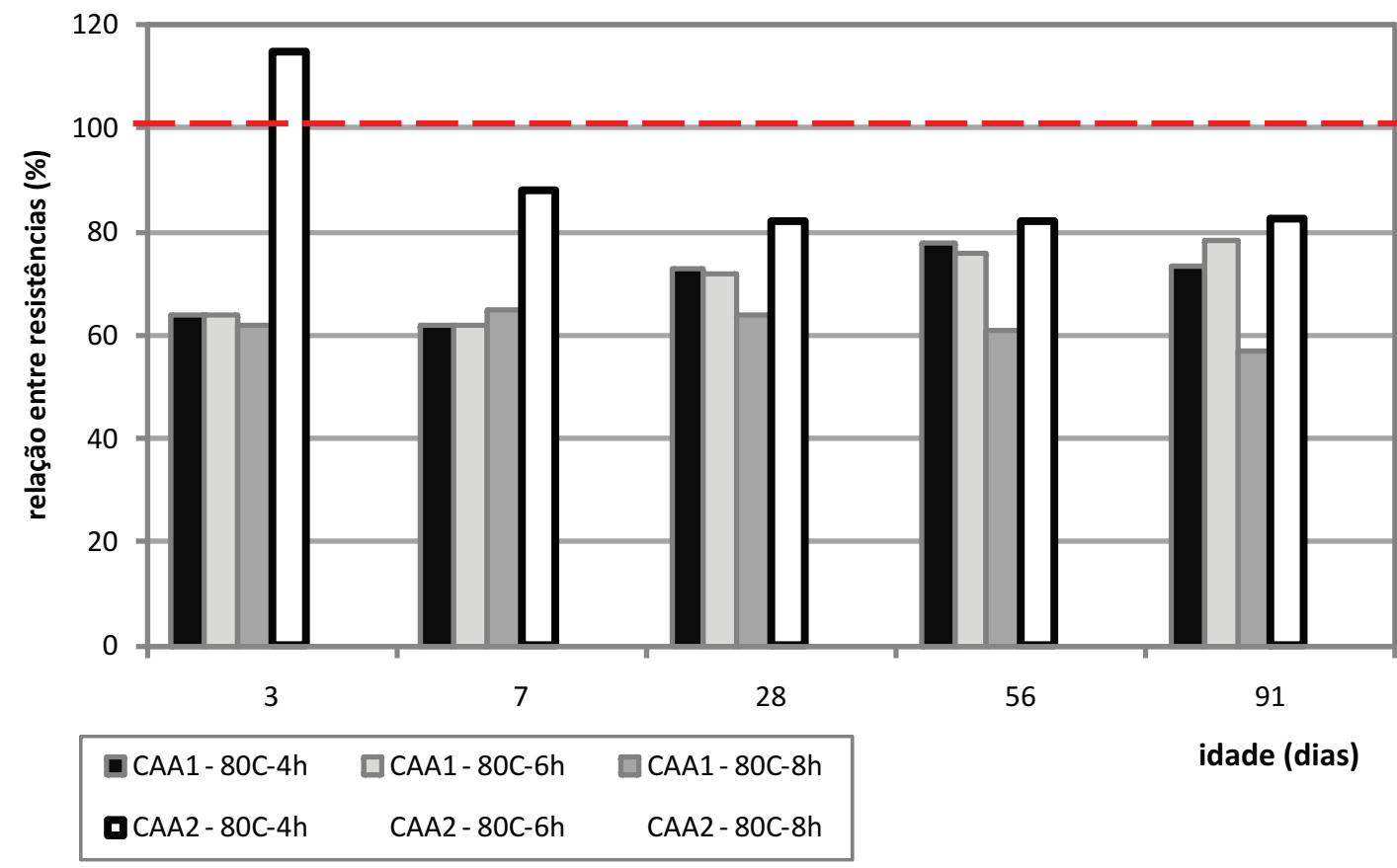


[06] WÜSTHOLZ, T. Fresh Proprieties of self-compacting concrete (SCC). Otto-Graf-Journal. Vol. 14. p 179-188, 2003.

[07] ABNT. Concreto auto-adensável. NBR15823. Rio de Janeiro, 2010.

[08] ALENCAR, R.S.A. Dosagem do concreto auto-adensável: produção de pré-fabricados. Dissertação de mestrado, Universidade de São Paulo. 179p. São Paulo,2008.

[09] TUTIKIAN, B. F. Métodos para dosagem de concretos self-compacting. Dissertação de Mestrado. Universidade Federal do Rio Grande do Sul, 148p, 2004.

[10] MELO, K.A.. Contribuição à dosagem de concreto auto-adensável com adição de filer calcário. Dissertação de mestrado, UFSC, Florianópolis, SC. 180p, 2005

[11] ASAGA, K.; ISHIZAKI, M.; TAKAHAGH, S.; KONISH, $\mathrm{K}$; TSURUMI, T.; DAIMON, M. effect of curing temperature on the hydration of portland cement compounds. in: 9th international conference on computer communication, 1992. Deli. Anais. Deli: ICCC, 1992.

[12] CAMARINI, G. Desempenho de misturas cimento Portland e escória de alto-forno submetidas à cura térmica. Tese de Doutorado - Escola Politécnica, Universidade de São Paulo, São Paulo. 252 p,1995.

[13] EL DEBS, M. K. Concreto pré-moldado: fundamentos e aplicações. São Carlos: EESC - USP. 456p, 2000.

[14] AMERICAN CONCRETE INSTITUTE (ACI). Accelerated curing of concrete at atmospheric pressure-state of the art. ACI 517.2 R-87, Manual of Concrete, 1992.

[15] TÜRKEL, S.; ALABAS, V. The effect of excessive steam curing on Portland composite cement concrete. Cement and Concrete Research, vol.35, p. 405-411, 2005.

[16] ABNT. Agregado graúdo - Determinação de massa específica, massa específica aparente e absorção de água. NBR NM 53. Rio deJaneiro, 2003.

[17] ASOCIACIÓN MERCOSUR DE NORMALIZACIÓN AMN. NM 248: Agregados - Determinação da composição granulométrica. Rio de Janeiro: ABNT, 2001. 6 p.

[18] TAYLOR, H. F. W. Cement Chemistry. Academic Press Ltd. London, 1990.

[19] SANTOS, L.F. A influência do patamar de cura térmica sobre a resistência dos concretos self-compacting elaborados com diferentes tipos de cimento: avaliação pelo método da maturidade. Dissertação de mestrado, UNESP, Ilha Solteira, SP. 279p, 2010. 